\title{
Effects of Scilla autumnalis Extracts on U87-MG Human Glioblastoma Cells
}

\author{
Scilla autumnalis Ekstrelerinin U-87 MG Insan Glioblastoma Hücreleri Üzerinde Etkileri
}

\author{
Murat Pekmez', Cagatay Tarhan', Ali Zeytunluoglu², Murat Turan³, Sefika Beyza Mete'1, Aylin Koseler ${ }^{4}$ \\ ${ }^{1}$ Department of Molecular Biology and Genetics, Istanbul University Faculty of Science, Istanbul; ${ }^{2}$ Department of Electronics \\ and Automation, Pamukkale University Vocational School of Technical Sciences, Denizli; ${ }^{3}$ Department of Molecular Biology and \\ Genetics, Faculty of Science, Erzurum Technical University, Erzurum; ${ }^{4}$ Department of Biophysics, Pamukkale University Faculty of \\ Medicine, Denizli, Turkey
}

\begin{abstract}
Aim: This study aimed to measure the effects of Scilla autumnalis extracts which might act as potential plant based chemotherapeutic, on U87 glioblastoma cell line.
\end{abstract}

Material and Method: Cytotoxicity assays were performed by determining the cell viability of the samples with MTT (3 - (4, 5-dimethylthiazol-2-yl)-2, 5-diphenyltetrazolium bromide). Gene expression levels of glucose transporter 1 (GLUT1), Glucose transporter 3 (GLUT3), Glucose transporter 4 (GLUT4), Hexokinase 1 (HK1) and Hexokinase 2 (HK2), multidrug resistance1 (MDR1), Cytochrome P450 Family 2 Subfamily E Member 1 (CYP2E1) and Pregnane $X$ receptor (PXR) was analyzed in glioblastoma cells using quantitative real-time $R T$-PCR.

Results: According to the analysis, we observed a $10 \%$ increase in the expression of Glut1, however, we did not observe a difference in Glut3 expression. For Glut4, root ethanol extract decreased its expression by $13 \%$ but shoot extracts elevated the expression levels by only 5-6\%. We determined the low expression levels of HK1 and HK2 in glioblastoma compared to the control group. S.autumnalis root extract led to a slight increase in MDR1 expression. We found that the expression level of CYP2E1 was $20 \%$ lower in glioblastoma cells treated with Scilla autumnalis root and shoots extracts compared to the control group. We determined downregulation in PXR expression.

Conclusion: This study may contribute significantly to the understanding of the cytotoxic effect of Scilla autumnalis. This approach may allow the possibility of Scilla autumnalis plant extract as a candidate drug for the treatment of glioblastoma.

Key words: Scilla autumnalis; glioblastoma; cancer treatment

\section{ÖZET}

Amaç: Bu çalıșmada U87 glioblastoma hücre hattı üzerinde bitkisel temelli kemoterapötik olarak davranma potansiyeli tașıyan Scilla autumnalis özütünün etkisinin ölçülmesi amaçlanmıștır.

Materyal ve Metot: Sitotoksisite deneyleri örneklerin canlı̈̆̆ının MTT (3 - (4, 5-dimethylthiazol-2-yl)-2, 5-diphenyltetrazolium bromide) yöntemiyle belirlenmesiyle saptanmıștır. Glioblastoma hücreelerindeki Glukoz transporter 1 (GLUT1), Glukoz transporter 3 (GLUT3), Glukoz transporter 4 (GLUT4), Heksokinaz 1 (HK1) and Heksokinaz 2 (HK2), Multidrug resistance1 (MDR1), Cytochrome P450 Family 2 Subfamily E Member 1 (CYP2E1) ve Pregnane $X$ receptor (PXR) gen anlatım düzeyleri kantitatif $R T-P C R$ kullanılarak analiz edilmiștir.

Bulgular: Elde edilen sonuçlara gore GLUT1 anlatımı \%10 düzeyinde artarken GLUT3 anlatımında bir değișiklik saptanmamıștır. Kök etanol özütü GLUT4 anlatımını \%13 kadar azaltırken gövde özütü \%5-6 civarında artırmıștır. Glioblastomadaki HF1 ve HK2 anlatım düzeyleri control grubuna gore önemli ölçüde düșük olarak bulunmmuștur. S.autumnalis kök özütü MDR1 anlatımında küçükbir miktar artıșa yol açmıștır. CYP2E1'nin anlatım düzeyinin S. autumnalis'in kök ve gövde özütü uygulanmıș glioblastoma hücrelerinde kontrol grubuna göre \%20 oranında düștüğü saptanmıșken PXR anlatımının da azaldığı gözlemlenmiștir.

Sonuç: Bu çalıșma S.autumnalis'in sitotoksik etkisinin anlașılmasına önemli bir katkı sunabilir. Bu yaklașım S.autumnalis bitki özütünün glioblastoma tedavisinde aday ilaç olarak kullanılabileceğine ișaret etmektedir.

Anahtar kelimeler: Scilla autumnalis; glioblastoma; kanser tedavisi

Iletișim/Contact: Murat Pekmez, Istanbul University Faculty of Science, Department of Molecular Biology and Genetics, Istanbul, Turkey • Tel:053627743 17 • E-mail:mpekmez@istanbul.edu.tr • Geliș/Received:24.09.2020 • Kabul/Accepted: 13.06.2021

ORCID: Murat Pekmez, 0000-0002-6150-8372 • Çağatay Tarhan, 0000-0001-5265-4610 • Ali Zeytünlüoğlu, 0000-0002-2534-7241 • Murat Turan, 0000-0003-2900-1755 • Şefika Beyza Mete, 0000-0002-3386-6244 • Aylin Köseler, 0000-0003-4832-0436 


\section{Introduction}

Glioblastoma multiforme (GBM) is the most common malignant primary brain tumor in adults, which is also difficult to diagnose and treat. The treatment has not changed over the years ${ }^{1,2} .90 \%$ of cases develop de novo (primary glioblastoma) from normal glial cells with multistep tumorigenesis. The remaining 10\% glioma is secondary neoplasm cases that progress from low-grade tumors (diffuse or anaplastic astrocytomas) lasting 4-5 years ${ }^{3,4}$. The main developmental location of glioblastoma multiforme is the brain. The tumor is indistinguishable from normal tissue because it is characterized by infiltrating growth ${ }^{1,5}$. It is localized in the hemispheres or subcutaneously in the brain stem and the cerebellum ${ }^{6,8}$. The result may sometimes be hydrocephaly, as a growing tumor causes increased intracranial pressure?.

As it is known, cancer, which caused approximately 8.2 million deaths in 2012, is one of the most common diseases ${ }^{10}$. The effect of various risk factors, including age, geographical region, and race, on cancer development, has been reported ${ }^{11}$. Although chemotherapy is the main treatment approach, resistance to chemotherapeutic drugs has been observed in $30-80 \%$ of cancer patients in recent years. Therefore, plant-based substances have received great interest among researchers. Plant kingdom comprised approximately 250000 plant species but nearly $10 \%$ of them have been studied for the treatment of different diseases. That's why it is important to evaluate the potential of untested or endemic plant species extracts or their purified compounds.

The Hyacinthaceae family has approximately 900 species in about 70 genera in the world ${ }^{12}$. Scilla species are widely used in folk medicine in the treatment of different illnesses. As phytochemical compounds, the alkaloids, cardiac glycosides, ergosterol glycosides, triterpenoids, triterpenoids glycosides, nortriterpenoids glycosides, stilbenes, and homoisoflavanoids was reported $^{13,14}$. These compounds are responsible for a large number of different biological activities such as analgesic $^{15,16}$, anti-tumoral ${ }^{12,17-20}$, anti-inflammatory ${ }^{16,21-24}$, anti-oxidative ${ }^{22}$, and antioxidant ${ }^{24-26}$.

Scilla autumnalis is found in the Mediterranean region from Portugal to Turkey and the Caucasus ${ }^{26}$. There are only a few data on the anti-tumoral activity of the Scilla species, however, there are no data on the anti-tumoral activity of Scilla autumnalis. In the present study, we assessed the anti-tumoral effects of Scilla autumnalis extracts on glioblastoma multiforme.

\section{Materials and Methods}

\section{Preparation of Plant Extract}

Scilla autumnalis was collected from Denizli, Turkey. The herbarium sample was separated from the collected plant samples and stored in the Herbarium of the University of Pamukkale, Denizli, Turkey (Voucher specimen number: RM1002). Systematic identification of the collected plant species was made using reference books and identification keys.

The plant extraction was performed with method described by Mammadov et al. ${ }^{26}$ Firstly, the root (7) and shoot (8) parts of plants were dried in the shade and were powdered with grinder. $10 \mathrm{~g}$ plant sample was added into erlenmayer which contains $100 \mathrm{~mL}$ solvent $[$ ethanol $(\mathrm{G})$ or methanol $(\mathrm{H})]$ and then shaked at $50^{\circ} \mathrm{C}$ for $6 \mathrm{~h}$. The solvent extract was filtered and evaporated using rotary evaporator. The dry solvent extract was solved with distilled water and was frozed at $-80^{\circ} \mathrm{C}$. The frozed sample was lyophilized with lyophiphilizer. Obtained extracts were stored at $-20^{\circ} \mathrm{C}$ until use.

\section{U87 Glioblastoma Cell Line}

U87 MG cells were used from the cell culture collection of Molecular Biology and Genetics Department, Istanbul University. The cells that were used in the experiments had a passage number between 6-9. Gliobalstoma cells were grown and subcultured in Dulbecco's Modified Eagle Medium (DMEM) supplemented with Glucose $(4.5 \mathrm{mg} / \mathrm{mL}), 10 \%$ Fetal Bovine Serum (FBS), 1\% antibiotics and antimycotic (penicillin, streptomycin and amphotericin B) and 1\% nonessential amino acids (NEAA) at $37^{\circ} \mathrm{C}$ with $5 \% \mathrm{CO}_{2}$ in an incubator.

\section{Cytotoxicity Assay}

Cytotoxicity assays were performed by determining the cell viability of the samples with MTT (3- (4, 5-dimethylthiazol-2-yl)-2, 5-diphenyltetrazolium bromide) assay Briefly, U87MG cells $\left(1.5 \times 10^{4}\right.$ per well) were seeded in 96-well plates and incubated at $37^{\circ} \mathrm{C}$ for $24 \mathrm{~h}$. Different concentrations of $7 \mathrm{G}, 8 \mathrm{G}, 8 \mathrm{H}(1,5$, $10,25,50,100,250,500,1000 \mu \mathrm{g} / \mathrm{mL}$ ) were tested on the cells for 24, 48 and $72 \mathrm{~h}$. After treatments, the cells were incubated with MTT at a final concentration of $0.5 \mathrm{mg} / \mathrm{ml}$ at $37^{\circ} \mathrm{C}$ for $4 \mathrm{~h}$, followed by the addition of DMSO $(150 \mu \mathrm{l})$ to dissolve the formazan crystals. The absorbance of each well was measured at $570 \mathrm{~nm}$ 
using a microplate reader (EON, BioTek Instruments Inc., Winooski, VT, USA). Half-maximal inhibitory concentrations $\left(\mathrm{IC}_{50}\right)$ of the extracts were calculated by fitting the data to a sigmoidal dose-response curve using nonlinear regression analysis. All test samples were measured in triplicate.

\section{Gene Expression Analysis Using Quantitative Real-time RT-PCR Analysis}

Gene expression of GLUT1 (SLC2A1), GLUT3 (SLC2A3), GLUT4 (SLC2A4), Hexokinase 1 (HK1) and Hexokinase 2 (HK2), MDR, CYP2E1, PXR was analyzed in glioblastoma cells. After 48 hours of treatment with $S$. autumnalis root (ethanol) and shoot ethanol and methanol) extracts, total RNA was extracted with Human Blood RNA Purification Kit (GMBiolabs, Taichung City, Taiwan) according to the procedure recommended by the manufacturer. Conversion of total RNA to single-strand complementary DNA (cDNA) was done with High-Capacity cDNA Reverse Transcription Kit (Applied Biosystems Inc., Foster City, CA, USA) with random primers. Real-time PCR was performed with GM SYBR qPCR Kit (without ROX) (GMBiolab, Taichung City, Taiwan) with the specified conditions as initial denaturation at $95^{\circ} \mathrm{C}$ for 120 seconds (sec.), following 45 cycles at $95^{\circ} \mathrm{C}$ for $20 \mathrm{sec}$., at $55^{\circ} \mathrm{C}$ for $30 \mathrm{sec}$., at $72^{\circ} \mathrm{C}$ for $45 \mathrm{sec}$. Primer sequences and expected product lengths are given in Table 1. Expression of each target genes was normalized to the expression of Glyceraldehyde-3-Phosphate Dehydrogenase (GAPDH).

Table 1. Primers used in quantitative real-time RT-PCR

\begin{tabular}{|c|c|c|}
\hline Gene & Forward Primer 5'->3' & Reverse Primer 5'->3' \\
\hline HK1 & TCAGATCGAGAGTGACCGATT & CACACTGTCTTGACGAGGATAC \\
\hline HK2 & ACGAGAGTTTCCTGGTCTCA & TCAАAGTССССТСТССТCTG \\
\hline GLUT1 & GTTCATCGTGGCTGAACTCT & ACAGTTGCTCCACATACTGG \\
\hline GLUT3 & СGCCTGATTATTGGCATCTT & TCCAAACCAAAGACCTGAGC \\
\hline GLUT4 & CAGTATGTTGCGGAGGCTAT & AGTTCTGTGCTGGGTTTCAC \\
\hline CYP2E1 & ATGTCTGCCTCGGAGTGA & GGAAGAGGTTCCCGATGATG \\
\hline MDR & TGGCACCCAGCACAATGAA & CTAAGTCATAGTCCGCCTAGAAGCA \\
\hline PXR & GGCCACTGGCTATCACTTCAA & GTTTCATGGCCCTCCTGAAA \\
\hline
\end{tabular}

\section{Statistical Analysis}

Statistical software Graph Pad Prism 6.0 (Graph Pad, San Diego, CA) was used for all statistical analyses. $\mathrm{IC}_{50}$ values were calculated with non-linear regression analysis.

\section{Results}

Cytotoxicity on glioblastoma cells. To evaluate the cytotoxic effects of extracts on U87MG cells and determine $\mathrm{IC}_{50}$ value, the MTT cell viability test was performed after $24 \mathrm{~h}, 48 \mathrm{~h}$, and $72 \mathrm{~h}$. In the experiments, the final DMSO concentration did not exceed $0.75 \%$ and this concentration does not affect cell viability. The results showed that all of the extracts $(7 \mathrm{G}, 8 \mathrm{G}$, and $8 \mathrm{H}$ ) inhibit U87MG cell proliferation in a dose-dependent manner. For further experiments $48 \mathrm{~h}$ incubation was chosen and $\mathrm{IC}_{50}$ values were calculated as $79.04 \mu \mathrm{g} / \mathrm{mL}, 237.342 \mu \mathrm{g} /$ $\mathrm{mL}, 188.919 \mu \mathrm{g} / \mathrm{mL}$ respectively for $7 \mathrm{G}, 8 \mathrm{G}$, and $8 \mathrm{H}$. The ethanolic root extract has the most inhibitory effect on the U87 glioma cell line. The effect of different extracts on the survival of the U87 glioblastoma cell line was shown in Fig 1, Fig 2, and Fig 3. In our study, gene expression of GLUT1 (SLC2A1), GLUT3 (SLC2A3), GLUT4 (SLC2A4), Hexokinase 1 (HK1) and Hexokinase 2 (HK2), MDR, CYP2E1, PXR was analyzed. The expression profile of the groups was shown in Fig 4.

\section{Discussion}

$85-90 \%$ of primary central nervous system (CNS) tumors are brain tumors. Glioblastoma (GBM) accounts for approximately half of all malignant adult brain tumors and is associated with the shortest survival ${ }^{27}$. After the resistance to chemotherapeutics, natural product-based therapy has started to be used. This method has gained popularity as a potentially less toxic treatment. Podophyllotoxin and its semi-synthetic derivatives, Teniposide, Etoposide, and Etopophos, have been extensively used to treat many cancers ${ }^{28}$. Plant-based products have long been involved in cancer treatment. Their effect in this treatment is used to influence cancer development, progression, and metastasis. Some studies have demonstrated antitumor potential in the use of this plant-based therapy alone or combination with radiotherapy. During the $1960 \mathrm{~s}$ and $1985 \mathrm{~s}$, the National Cancer Institute (NCI) conducted an anti-cancer drug screening program. In this screening, 


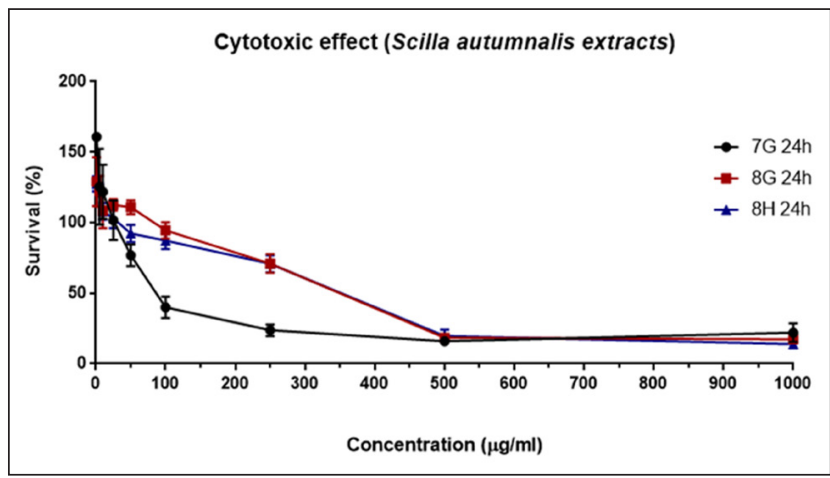

Figure 1. Effect of Scilla autumnalis root ethanolic (7G), shoot ethanolic (8G) and shoot methanolic (8H) extracts on the survival of U87 glioblastoma cells. Serially diluted (1-1000 $\mu \mathrm{g} / \mathrm{mL}$ ) extracts were added on U87 cells and incubated for 24 hours. Cell viability was evaluated with MTT assay. Line graphs were obtained with GraphPad Prism 7.0.

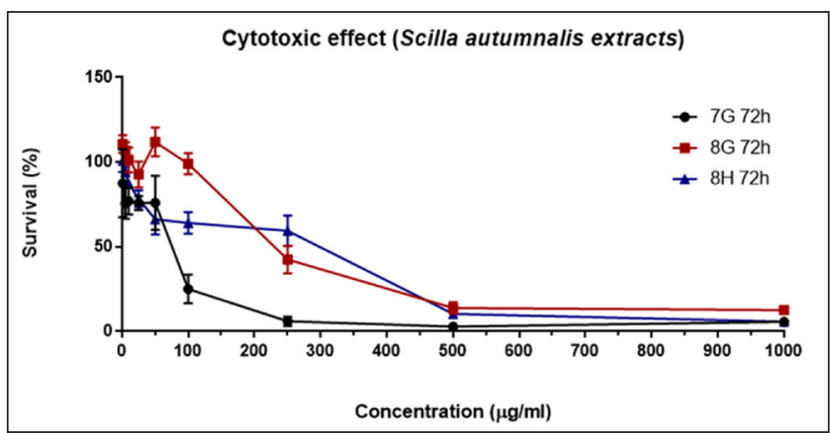

Figure 3. Effect of Scilla autumnalis root ethanolic (7G), shoot ethanolic (8G) and shoot methanolic (8H) extracts on the survival of U87 glioblastoma cells. Serially diluted (1-1000 $\mu \mathrm{g} / \mathrm{mL})$ extracts were added on U87 cells and incubated for 72 hours. Cell viability was evaluated with MTT assay. Line graphs were obtained with GraphPad Prism 7.0.

an important compound, Taxol (paclitaxel) isolated from the bark of Taxus brevifolia, used to treat many solid tumors, was identified ${ }^{29,30}$.

It has been investigated the toxicological properties of Scilla species in the various cancer cell lines: A 15-deoxoeucosterol oligosaccharide isolated from Scilla peruviana $L$. was found to be toxic to against cervical cancer (HeLa cells) ${ }^{12}$. The four compounds isolated from Scilla luciliae was showed the cytotoxic activity against Human Oral Squamous Cell Carcinoma (HSC-2) cells $^{31}$. The homoisoflavanones isolated from Scilla nervosa have been effective significantly against colon cancer (HT-29) and breast cancer (MDAMB-435) cell lines ${ }^{20}$. Scillascillin isolated from the fresh bulb of Scilla scilloides showed significantly active against human cancer cell lines MCF-7 (breast cancer) and DU-145 (prostate cancer) ${ }^{32,33}$. The scilla scilloside E-1 isolated from Scilla scilloides were evaluated for their cytotoxic

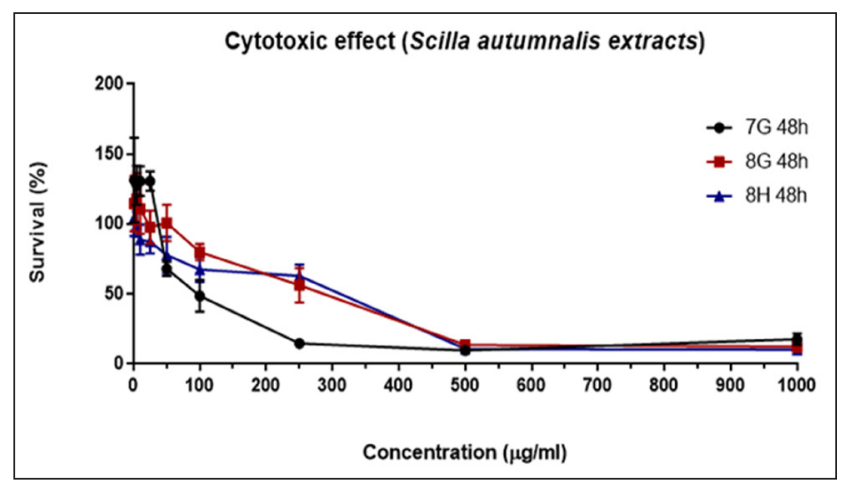

Figure 2. Effect of Scilla autumnalis root ethanolic (7G), shoot ethanolic (8G) and shoot methanolic (8H) extracts on the survival of U87 glioblastoma cells. Serially diluted (1-1000 $\mu \mathrm{g} / \mathrm{mL})$ extracts were added on U87 cells and incubated for 48 hours. Cell viability was evaluated with MTT assay. Line graphs were obtained with GraphPad Prism 7.0.

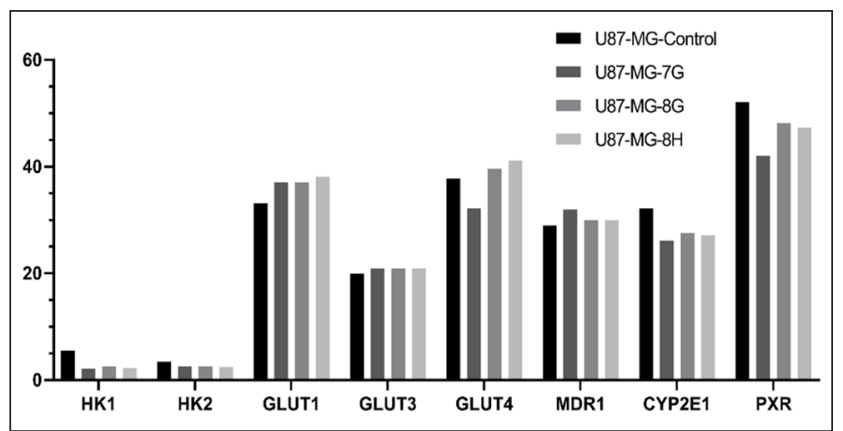

Figure 4. Gene expression of Hexokinase 1 (HK1) and Hexokinase 2 (HK2), Glucose transporter 1 (GLUT1), Glucose transporter 3 (GLUT3), Glucose transporter 4 (GLUT4), multidrug resistance 1 (MDR1), Cytochrome P450 Family 2 Subfamily E Member 1 (CYP2E1) and Pregnane $X$ receptor (PXR). Scilla autumnalis root ethanolic (7G), shoot ethanolic (8G) and shoot methanolic (8H) extracts.

activity against eight cancer lines in vitro and in vivo experiments. Particularly, it was found to be more effective against Fibrosarcoma Tumor (HT1080) ${ }^{19}$. The phenolic compounds isolated from Scilla autumnalis was showed a significant effect against human lung cancer (H1299) in vitro conditions ${ }^{26}$. Research studies have shown that Scilla species are associated with many types of cancer and have demonstrated their effectiveness.

When we investigated the inhibitory effect of $S$. autumnalis extracts on the proliferation of U87 cells, we observed that $500 \mu \mathrm{g} / \mathrm{ml}$ of both root and shoot extracts decreased the survival of more than $50 \%$ in all tested conditions. However, root extract was more effectively such that even $100 \mu \mathrm{g} / \mathrm{ml}$ inhibited U87 cells by $50 \%$. This indicates the importance of analyzing especially the root content and revealing effective compounds. 
Enhanced glycolysis is one of the most important cancer metabolic hallmarks ${ }^{34,35}$. In neurons, glucose uptake is facilitated by a family of glucose transporters (GLUTs) with the glucose transporter 1 (GLUT1) and 3 isoforms are believed to be responsible for the majority of glucose uptake within the brain ${ }^{36}$. As early as 1992, differential expression of glucose transporters has been noted in various grades of glioma, with an observed upregulation of GLUT1, the most prevalent type of GLUT ${ }^{37}$. There was contention as to whether GLUT1 was overexpressed ${ }^{37}$ or underexpressed ${ }^{38}$ in GBM, but it is now believed that there are areas of which both increase and decrease in GLUT1 expression was observed in GBM tissue ${ }^{39}$. The most significant overexpression of the glucose transporters was observed in the intermediate zone of the tumor ${ }^{40}$. In this study, we observed a $10 \%$ increase in the expression of Glut 1 following the treatment of Scilla autunmalis, however, we did not observe the differences in glucose transporter 3 (GLUT3) expression. In another study, it was observed in biopsied glioblastoma that while expression of GLUT1 and GLUT3 was not significantly changed, glucose transporter 4 (GLUT4) expression was relatively low ${ }^{41}$. In our study, following Scilla autunmalis extract treatment for 48 hours, we observed a $10 \%$ increase in the expression of Glut 1 , however, we did not observe a difference in Glut 3 expression. As for Glut4, root ethanol extract decreased its expression by $13 \%$ but shoot extracts elevated the expression levels by only $5-6 \%$. In various studies, different extracts or even purified phytochemicals showed variable effects on GLUT gene expression depending on the cancer type. For example, Resveratrol, a trihydroxystilbene, inhibited GLUT1 and thereby the glucose uptake in human leukemic cell lines ${ }^{42}$. Similarly, Rubusoside (a steviol glycoside), curcumin (flavanoid) and plumbagin (naphthoquinone) have also been shown to have a down-regulating activity on GLUT1 expression ${ }^{43,44}$. On the other hand, daidzein (isoflavone) and epigallocatechin gallate (catechin) cause elevated GLUT1 expression in breast cancer. Thus, differential expression of GLUT genes may result from combined effects of the phytochemical content of the root.

The Cytochrome P450 enzyme family contains several subcategories (CYP1, CYP2, and CYP3) which are responsible for the breakdown of foreign compounds in mammals. Cytochrome P450 Family 2 Subfamily E Member 1 (CYP2E1) can also activate toxic compounds and procarcinogens found in tobacco smoke and nitrosamine compounds ${ }^{45}$. In the previous study; it has been determined as slightly induced with Scilla nervosa aqueous extract of CYP3A 4 activity $^{46}$. In our study, we found that the expression level of CYP2E1 was 20\% lower in glioblastoma cells treated with Scilla autumnalis root and shoots extracts compared to the control group. Because CYP2E1 metabolizes the aforementioned molecules and pro-carcinogens such as nitrosamines and azo compounds ${ }^{47}$ and metabolism of these molecules produce toxic intermediates and reactive oxygen species that cause various pathological conditions $^{48}$, elevated expression of CYP2E1 may also be responsible for cancer progression. A study, suggest a possible link between CYP2E1 activity and breast cancer through ethanol metabolism ${ }^{49}$. On the other hand, it was shown in another study that CYP2E1 is upregulated in the nontumor tissue and downregulated in tumor tissue in hepatocellular carcinoma ${ }^{50}$. Thus, a natural therapeutic target must be evaluated in each cancer cell type.

P-glycoprotein (P-gp), a $170-\mathrm{kDa}$ protein encoded by the multiple drug resistance human (MDR1) gene, which is a member of the ABC superfamily of energy-dependent transport systems. P-gp displays broad specificity, accepting many structurally, functionally, and mechanistically unrelated compounds and its role in limiting drug penetration across biological barriers is well established ${ }^{51}$. An enhancement of $A B C$ transporter expression represents one of the major MDR mechanisms that protect cancer cells from different drugs. Nardinocchi et al. observed that the downregulation of HIF-1alfa was associated with a decrease in MDR1 transcript levels ${ }^{51}$. In this study, we observed that especially $S$. autumnalis root extract led to a slight increase in MDR1 expression. Although it can be considered as a drawback for the outcome of chemotherapy, the root extract itself is more toxic to glioblastoma cells than shoot extracts even lower doses. So it seems that the total effect of the extract on glioblastoma overshades this slight increase.

Pregnane $\mathrm{X}$ receptor (PXR) are known major nuclear transcription factors in regulating drug efflux transporters and also plays a role in cell proliferation, apoptosis, carcinogenesis and cancer treatments ${ }^{52}$. PXR can alter the outcome of chemotherapy in different cancers by regulating especially drug metabolism, drug transport, proliferation, and apoptosis. But it seems that the PXR expression may be context-specific in these cancers. For example, it was reported that, in human prostate cancer, 
PXR expression was higher in cancerous tissues when compared to normal tissues ${ }^{53}$. In breast cancers, some studies suggested elevated PXR expression in cancer tissue ${ }^{54}$ but others reported no significant difference in the expression between healthy and cancerous tissues ${ }^{55}$. Besides, in breast cancer, pharmacologic induction of PXR causes a significant expression of MDR1 and resistance to Taxol ${ }^{56}$. According to our results, $S$. autumnalis extract downregulated the PXR expression. This reflects the importance of cancer type or the context specificity when an anti-cancer plant, natural product or a drug is considered as a therapeutic agent.

Hexokinases ( $\mathrm{HK}$ ) are comprised of a family of four isoforms. Hexokinase 1 (HK1) and Hexokinase 2 (HK2) are the most abundant, with HK1 ("the brain HK”) ubiquitous in most tissues, especially brain and red blood cells where glycolysis plays a critical role in energy production. When compared to normal cells, tumor cells preferentially utilize this far less efficient process for ATP production, which also increased the cell's proliferation, invasiveness, and apoptosis resistance. This high rate of glycolysis in tumor cells, including glioma cells, was presumably ascribed to the up-regulation of key catalytic enzymes in glycolysis, especially hexokinases, more specifically HK2. In addition to its critical metabolic role, $\mathrm{HK} 2$ could also promote glioma survival, against chemo or radiation insult, by repressing mitochondria-mediated apoptotic pathway in glioma cells ${ }^{57}$. Here in this study, we determined the low expression levels of HK1 and HK2 in glioblastoma compared to the control group. In two different studies, the inhibition of HK2 by some chemicals such as 2-deoxy-D-glucose (2-DG) or by 3-bromopyruvate (3BP) was shown to inhibit glycolysis in tumor cells $s^{58,59}$. But the potential toxicity of these chemicals to normal cells limits their use in cancer treatment. Therefore, it becomes very important to find natural products that do not have such side effects. In this study, we determined the expression levels of HK1 and HK2 in glioblastoma were nearly $55 \%$ lower than the control group when treated with $S$. autumnalis root and shoot extracts. Several phytocompounds exert HK2 downregulating activity. For example, a bioactive flavone chrysin was shown to decrease of HK2 expression, thereby glucose uptake and tumor glycolysis in hepatocellular carcinoma (Chrysin inhibited tumor glycolysis and induced apoptosis in hepatocellular carcinoma by targeting HK2). Other compounds, such as betulinic acid and ursolic acid also have HK2 downregulating activity ${ }^{60}$.
All these results suggest that despite the other effects of $S$. autumnalis plant extract, the cytotoxic effect on glioblastoma is mediated by reducing the level of $\mathrm{HK} 1$ and HK2 expressions. S. autumnalis plant extract may be a candidate, especially for glioblastoma treatment drugs. Mechanism of action, chemical properties for the usage in glioblastoma and the effect of the extract on glioblastoma could be the further issues to be considered.

\section{Authors' Contributions}

A. K., Ç. T., M. P., and A. Z. designed the study. A. K., Ç. T., M. P., and A. Z. analyzed data. A. K., M. T., and Ş. B. M. performed experiments, A. K., Ç. T., M. P., and A. Z. contributed ideas and insights. A. K., Ç. T., M. P., and A. Z. wrote the article with input from all Authors.

\section{Conflicts of Interest}

The authors declare no competing interests regarding this study.

\section{References}

1. Karcher S, Steiner HH, Ahmadi R, Zoubaa S, Vasvari G, Bauer $\mathrm{H}$ et al. Different angiogenic phenotypes in primary and secondary glioblastomas. Int J Cancer 2006;18:2182-2189.

2. Moore MP, Bagley RS, Harrington ML and Gavin PR. Intracranial tumours. Clin North Am Small Anim Pract Vet 1996;26:759-777.

3. Kabat GC, Etgen AM and Rohan TE. Do steroid hormones play a role in the etiology of glioma? Cancer Epidemiol Biomarkers Prev 2010;19:2421-27.

4. Tso CL, Freije WA, Day A, Chen Z, Merriman B, Perlina A, et al. Distinct transcription profiles of primary and secondary glioblastoma subgroups. Cancer Res 2006;66:159-167.

5. Zhen L, Yufeng C, Zhenyu S and Lei X. Multiple extracranial metastases from secondary glioblastoma multiforme: a case report and review of the literature. J Neurooncol 2010;99:165-176.

6. Krex D, Klink B, Hartmann C, von Deimling A, Pietsch $\mathrm{T}$, Simon $\mathrm{M}$, et al. Long-term survival with glioblastoma multiforme. Brain 2007;130:2596-2606.

7. Lakhan SE and Harle L. Difficult diagnosis of brainstem glioblastoma multiforme in a woman: a case report and review of the literature. J Med Case Rep 2009;3:87.

8. Hur H, Jung S, Jung TY and Kim IY. Cerebellar glioblastoma multiforme in an adult. J Korean Neurosurg Soc 2008;43(4):194-197.

9. De Castro-Costa CM, de Araújo RW, de Arruda MA, de Araújo PM and de Figueiredo EG. Increased intracranial pressure in a case of spinal cervical glioblastoma multiforme. Analysis of these two rare conditions. Arq Neuropsiquiatr 1994;52:64-8. 
10. Torre LA, Bray F, Siegel RL, Ferlay J, Lortet-Tieulent J and Jemal A(2015)Global cancer statistics, 2012. CA Cancer J Clin 65(2):87-108.

11. Millimouno FM, Dong J, Yang L, Li J, and Li X. Targeting apoptosis pathways in cancer and perspectives with natural compounds from mother nature. Cancer Prev Res (Phila)2014;7(11):1081-1107.

12. Mulholland DA, Schwikkard SL and Crouch NR. The chemistry and biological activity of the Hyacinthaceae. Nat Prod Rep 2013;30(9):1165-1210.

13. Ghoran SF, Pouneh Ebrahimi P, Hossein Mighani $\mathrm{H}$ and Soudabeh Saeidnia S. Isolation and characterization of homoisoflavonoids from Scilla persica Hausskn. Brazilian Journal of Pharmaceutical Sciences 2015;51(4):949-955.

14. Ghoran SF, Saeidnia S, Babaei E, Kiuchi F and Hussain H Scilla persicene: a new homoisoflavonoid with cytotoxic activity from the bulbs of Scilla persica Hausskn. Natural Product Research 2016;30(11):1309-1314.

15. Kalaiselvan M and Gopalan R. Ethnobotanical studies on selected wild medicinal plants used by Irula tribes of bolampatty valley, nilgiri biosphere reserve (NBR), southern Western Ghats, India. Asian Journal of Pharmaceutical and Clinical Research 2014;7(1):22-26.

16. Du Toit K, Kweyama A and Bodenstein J. Anti-inflammatory and antimicrobial profiles of Scilla nervosa (Burch.)Jessop (Hyacinthaceae). South Afr J Sci 2011;107(5-6):96-100.

17. Clark AM. Natural Products as a Resource for New Drugs. Pharmaceutical Research 1996;13(8):1133-1141.

18. Mimaki Y, Nishino H, Kuroda M, Matsui T and Sashida Y. Lanosterol Oligosaccharides from the Plants of the Subfamily Scilloideae and Their Antitumor Promoter Activity. Chemical and Pharmaceutical Bulletin 1994;42(2):327-332.

19. Lee HB and Lee SM. Antimicrobial Activity of Eucosterol Oligosaccharides Isolated from Bulb of Squill (Scilla scilloides). Pharmacology \& Pharmacy 2013;4:110-114.

20. Abegaz BM. Novel phenylanthraquinones, isofuranonaphthoquinones, homoisoflavonoids, and biflavonoids from African plants in the genera Bulbine, Scilla, Ledebouria, and Rhus. Phytochem Rev 2002;1:299-310.

21. Sakthivel K, Palani S, Selvaraj R, Venkadesan D, Sivasankari $\mathrm{H}$ and Senthil Kumar B. Cardioprotective and Antioxidant Potential of Scilla hyacinthina. Journal of Biological Sciences 2013;13(5):313-322.

22. Yeo EJ, Kim KT, Han YS, Nah YS and Paik HD. Antimicrobial, antiinflammatory and anti-oxidative activities of Scilla scilloides (Lindl.) Druce root extract. Food Sci Biotechnol, 2006;15:639-642.

23. Nishida Y, Sugahar S, Kensuke Wada K, Toyohisa D, Tanaka T, Ono $\mathrm{M}$ et al. Inhibitory effects of the ethyl acetate extract from bulbs of Scilla scilloides on lipoxygenase and hyaluronidase activities. Pharmaceutic al Biology 2014;52(10):1351-1357.

24. Alluri N, Ravi BV, Kumari H, Latha P, MAjumdar M. Evaluation of in vitro antioxidant, anti-inflammatory and thrombolytic activities of Scilla hyacinthina, an endangered medicinal plant. International Journal of Pharmacy and Pharmaceutical Sciences 2015;7(4):84-88.
25. Gupta LM and Raina R. Antioxidant property of the bulb of Scilla indica. Current Science 2001;80(10):1267-1269.

26. Mammadov R, Kaska A, Ozay C. Phenolic Composition, Antioxidant and Cytotoxic Activities of Prospero autumnale. Indian Journal of Pharmaceutical Sciences 2017;79(4):585590.

27. Ostrom QT, Gittleman H, Fulop J, Liu M, Blanda R, Kromer C. CBTRUS Statistical Report: Primary Brain and Central Nervous System Tumors Diagnosed in the United States in 2008-2012. Neuro Oncol 2015; 17: iv1-iv62.

28. Schacter L. Etoposide phosphate: what, why, where, and how? Semin Oncol 1996;23:1-7.

29. Mann J. Natural products in cancer chemotherapy: past, present and future. Nat Rev Cancer 2002;2:143-148.

30. Altmann $\mathrm{KH}$ and Gertsch J. Anticancer drugs from naturenatural products as a unique source of new microtubulestabilizing agents. Nat Prod Rep 2007;24:327-357.

31. Ori K, Kuroda M, Mimaki Y, Sakagami H and Sashida Y. Lanosterol and Tetranorlanosterolglycodised from the bulbs of Muscari paradoxum. Phytochemistry 2003;64(8):1351-1359.

32. Wang YM, Fan MY,LiJ, WangZM, Gao HM. Homoisoflavanones and stilbenes from fresh bulb of Scilla scilloides. Zhongguo Zhong Yao Za Zhi 2014;39(19):3788-3793.

33. Chinthala Y, Chinde S, Kumar AN, Srinivas KV, Kumar JK, Sastry KP, et al. Anticancer Active Homoisoflavone from the Underground Bulbs of Ledebouria hyderabadensis. Pharmacognosy Res 2014;6(4):303-5.

34. Cantor JR and Sabatini DM. Cancer cell metabolism: one hallmark, many faces. Cancer Discov 2012;2(10):881-898.

35. Hanahan D and Weinberg RA. Hallmarks of Cancer: The Next Generation. Cell 2011;144:646-674.

36. Duelli $\mathrm{R}$ and Kuschinsky W. Brain glucose transporters: relationship to local energy demand. News Physiol Sci 2001;16:71-76.

37. Nishioka T, Oda Y, Seino Y, Yamamoto T, Inagaki N, Yano H et al. Distribution of the glucose transporters in human brain tumors. Cancer Res 1992;52:3972-3979.

38. Tsukamoto H, Boado RJ and Pardridge WM. Differential expression in glioblastoma multiforme and cerebral hemangioblastoma of cytoplasmic proteins that bind two different domains within the 3'-untranslated region of the human glucose transporter 1(GLUT1)messenger RNA. J Clin Invest 1996;97:2823-2832.

39. Pistollato F, Abbadi S, Rampazzo E, Persano L, Della Puppa A, Frasson C. Intratumoral hypoxic gradient drives stem cells distribution and MGMT expression in glioblastoma. Stem Cells 2010;28:851-862.

40. Pistollato F, Rampazzo E, Persano L, Abbadi S, Frasson C, Denaro L et al. Interaction of hypoxia-inducible factor-1alpha and Notch signaling regulates medulloblastoma precursor proliferation and fate. Stem Cells 2010;28:1918-1929.

41. Nagamatsu S, Sawa H, Wakizaka A and Hoshino T. Expression of facilitative glucose transporter isoforms in human brain tumors. J Neurochem 1993;61(6):2048-2053. 
42. Zambrano A, Molt M, Uribe Eand Salas M. Glut 1 in Cancer Cells and the Inhibitory Action of Resveratrol as A Potential Therapeutic Strategy. Int J Mol Sci 2019;20(13):3374.

43. George Thompson AM, Iancu CV, Nguyen TT, Kim D and Choe JY. Inhibition of human GLUT1 and GLUT5 by plant carbohydrate products; insights into transport specificity. Sci Rep 2015:26(5):12804.

44. Liao H, Wang Z, Deng Z, Ren H and Li X. Curcumin inhibits lung cancer invasion and metastasis by attenuating glut $1 / \mathrm{mt} 1$ mmp/mmp2 pathway. Int J Clin Ex. Med 2015;8:8948-8957.

45. García-Suástegui WA, Ramos-Chávez LA, Rubio-Osornio M, Calvillo-Velasco M, Atzin-Méndez JA, Guevara J et al. The Role of CYP2E1 in the Drug Metabolism or Bioactivation in the Brain. Oxid Med Cell Longev 2017;4680732.

46. Pillay P, Phulukdaree A, Chuturgoon AA, Du Toit K and Bodenstein J The cytotoxic effects of Scilla nervosa (Burch.) Jessop (Hyacinthaceae) aqueous extract on cultured HepG2 cells. J Ethnopharmacol 145(1)2013;(1):200-204.

47. Gonzalez FJ. Mutant Role of cytochromes P450 in chemical toxicity and oxidative stress: studies with CYP2E1. Res 2005;569(1-2):101-110.

48. Knockaert L, Fromenty Band Robin MA. Mechanisms of mitochondrial targeting of cytochrome P450 2E1: physiopathological role in liver injury and obesity. FEBS J 2011;278(22):4252-4260.

49. Leung T, Rajendran R, Singh S, Garva R, Krstic-Demonacos M and Demonacos C. Cytochrome P450 2E1(CYP2E1)regulates the response to oxidative stress and migration of breast cancer cells. Breast Cancer Res 2013;15(6): R107.

50. Ho JC, Cheung ST, Leung KL, Ng IO and Fan ST. Decreased expression of cytochrome P450 2E1 is associated with poor prognosis of hepatocellular carcinoma. Int $\mathrm{J}$ Cancer 2004;111(4):494-500.

51. Da Ros M, De Gregorio V, Iorio AL, Giunti L, Guidi M, de Martino M, et al. Glioblastoma Chemoresistance: The Double Play by Microenvironment and Blood-Brain Barrier. Int J Mol Sci 2018;19(10): pii: E2879.
52. Zhuo W, Hu L, Lv J, Wang H, Zhou H and Fan L. Role of pregnane $\mathrm{X}$ receptor in chemotherapeutic treatment. Cancer Chemother Pharmacol 2014;74(2):217-227.

53. Chen Y, Tang Y, Wang MT, Zeng S, Nie D. Human pregnane $\mathrm{X}$ receptor and resistance to chemotherapy in prostate cancer. Cancer Res 2007;67:10361-10367.

54. Conde I, Lobo MV, Zamora J, Perez J, Gonzalez FJ, Alba E, et al. Human pregnane $\mathrm{X}$ receptor is expressed in breast carcinomas, potential heterodimers formation between hPXR and RXRalpha. BMC Cancer 2008;8:174.

55. Qiao EQ and Yang HJ. Effect of pregnane $X$ receptor expression on drug resistance in breast cancer. Oncology letters 2014;7:1191-1196.

56. Chen Y, Tang Y, Chen S and Nie D. Regulation of drug resistance by human pregnane $\mathrm{X}$ receptor in breast cancer. Cancer Biol Ther 2009;8:1265-1272.

57. Liu H, Liu N, Cheng Y, Jin W, Zhang P, Wang X. Hexokinase 2(HK2), the tumor promoter in glioma, is downregulated by miR-218/Bmil pathway. PLoS One 2017;12(12): e0189353.

58. Zhang D, Li J, Wang F, Hu J, Wang S and Sun Y 2-DeoxyD-glucose targeting of glucose metabolism in cancer cells as a potential therapy. Cancer Lett 2014;355(2):176-83.

59. Azevedo-Silva J, Queiros O, Baltazar F, Ulaszewski S, Goffeau A, Ko YH et al. The anticancer agent 3-bromopyruvate: a simple but powerful molecule taken from the lab to the bedside. J Bioenerg Biomembr 2016;48(4):349-362.

60. Lewinska A, Adamczyk-Grochala J, Kwasniewicz E, Deregowska A and Wnuk M. Ursolic acid-mediated changes in glycolytic pathway promote cytotoxic autophagy and apoptosis in phenotypically different breast cancer cells. Apoptosis 2017;22(6):800-815. 